\title{
GNAQ Gene Expression Analysis
}

National Cancer Institute

\section{Source}

National Cancer Institute. GNAQ Gene Expression Analysis. NCI Thesaurus. Code C89711.

A laboratory assay to determine the status of the GNAQ gene which encodes guanine nucleotide-binding protein $\mathrm{G}(\mathrm{q})$ subunit alpha. 